\title{
Synthesis and Mechanical Evaluation of Portland Cement Mortars Reinforced With Silicon Carbide Powder
}

\author{
J.F. Gamarra-Delgado1, M.L. Benavides-Salinas, V.C. Bringas-Rodríguez ${ }^{1}$, C.K. Palomino-Naupa, D.L. \\ Mayta-Ponce ${ }^{1}$, G.P. Rodríguez-Guillén ${ }^{1}$, R.M. Zapana-Vilcapaza ${ }^{1}$ \\ and F.A. Huamán-Mamani ${ }^{1}$ \\ ${ }^{1}$ Grupo de Investigación en Ciencia y Tecnología de Materiales, Departamento de Ciencias Naturales, Universidad \\ Católica San Pablo, Arequipa, Perú \\ Urb. Campiña Paisajista, Quinta Vivanco s/n, Arequipa 04001, Perú \\ frank.gamarra23@gmail.com; mirandabenavides7@gmail.com; veronicawnh@gmail.com; cpalominon@unsa.edu.pe; \\ dlmayta@ucsp.edu.pe; gprodriguez@ucsp.edu.pe; mzapana@gmail.com; fhuaman@ucsp.edu.pe
}

\begin{abstract}
Portland cement mortars reinforced with silicon carbide ( $\mathrm{SiC})$ powder were manufactured in this study. The volume of SiC powder added to the mixtures ranged from 0 to $8 \mathrm{vol} \%$ of the total volume of the mixtures studied, in addition the volume of SiC powder added replaced equivalent volumes of fine sand, within a standard mix of Portland cement mortars. (75 vol.\% of fine sand and 25 vol. $\%$ of Portland cement). SiC powder used was manufactured in the laboratory from the reuse of wood waste following wood pyrolysis processes to obtain carbon powder, followed by thermodiffusion of metallic silicon into pyrolyzed carbon powder.

All manufactured mortars were studied physical, microestructural and mechanically by helium pycnometry tests, optical microscopy and uniaxial compression, respectively. The average real density found for all mortars was $2.1 \mathrm{~g} / \mathrm{cm}^{3}$. The microstructure observed in mortars suggests the presence of three well-differentiated phases (Portland cement, fine sand and SiC particles), while the mechanical data found shows higher values of maximum resistance in mortars with $4 \mathrm{vol} \% \mathrm{SiC}$ added, which would appear to be the most suitable amount of $\mathrm{SiC}$ powder to be added to the Portland cement mortar mixture.
\end{abstract}

Keywords: silicon carbide, mechanical resistance, wood, powder, fine sand, reinforced agent

\section{Introduction}

Fabrication of biomorphic silicon carbide is made from wood precursors through pyrolysis process followed by silicon infiltration.

The compressive strength of these biomorphic composites was found to be strongly dependent on their bulk density and decreased as the test temperature increased [1,2]. Currently the wood industry in Peru generate large amounts of waste such as shavings, sawdust and large and small cuts of wood. Many times, these wastes are reused in certain types of industries as components or basic additives. It is starting to consider such waste as possible precursors for the manufacture of advanced materials $[3,4]$.

Silicon carbide manufactured from wood precursors (biomorphic $\mathrm{SiC}$ or bioSiC) has advantages due to its low production cost, the diversity of microstructures, as well as being able to generate elements with complex shapes. Biomorphic $\mathrm{SiC}$ is a material of proven potential in applications as structural reinforcers [5].

Biomorphic Silicon Carbide ( $\mathrm{SiC}$ ) has been widely used in industries due to its unique biological structure produced by natural wood. SiC exhibits excellent low density strength. The importance of the fabrication of SiC using wood precursor powders is based on the fact that the $\mathrm{SiC}$ ceramic produced is denser and the $\mathrm{SiC}$ is more homogeneous [6]. The demand for repair and strengthening of concrete structures is a current issue in civil construction [7]. The selection of an applicable strengthening material and method is essential in strengthening operations [8].

Deng [8] indicated that applying Highly ductile fiber-reinforced concrete (HDC) to strengthen the compression zone of an over-reinforced concrete beam is a highly effective method to change its brittle failure and improve the ductility showing an increase in flexural capacity and deformation.

A number of studies have been reported that the use of high ductile and high-performance cementitious fiber-reinforced composites mortar such as Engineered Cementitious Composites (ECC) mortar can significantly enhance the brittleness of concrete [9]. Fischer and $\mathrm{Li}[10,11]$ applied Engineered Cementitious Composites (ECC) mortar to improve the seismic performance of reinforced concrete columns and the effect of ductile deformation behavior of ECC. Resulting that the application of ECC to reinforced concrete members improves the deformation and load-carrying capacities. 


\section{Materials and methods}

Portland cement mortars reinforced with $\mathrm{SiC}$ powder were manufactured in two stages: (i) first, silicon carbide powder was manufactured from wood residues, through consecutive processes of pyrolysis of wood residues (in an inert atmosphere, $850^{\circ} \mathrm{C}, 1$ hour isotherm), thermodiffusion of metallic silicon into pyrolyzed carbon powder (in vacuum, $1450{ }^{\circ} \mathrm{C}, 1$ hour isotherm) and oxidative pyrolysis $\left(500^{\circ} \mathrm{C}\right.$, in air, 1 hour isotherm) and (ii) then Portland cement mortars reinforced with $\mathrm{SiC}$ powder were manufactured, according to the volumetric compositions of table 1. The mortar manufacturing process began with the dry mixing of the three components (table 1), then water was added in a water: cement ratio of 0.5 and mixing was continued until a plastic and workable paste was obtained. The plastic mortar mixture was pressed at $10 \mathrm{MPa}$ in a $20 \mathrm{~mm}$ diameter metal mold, then allowed to set in water for 28 days.

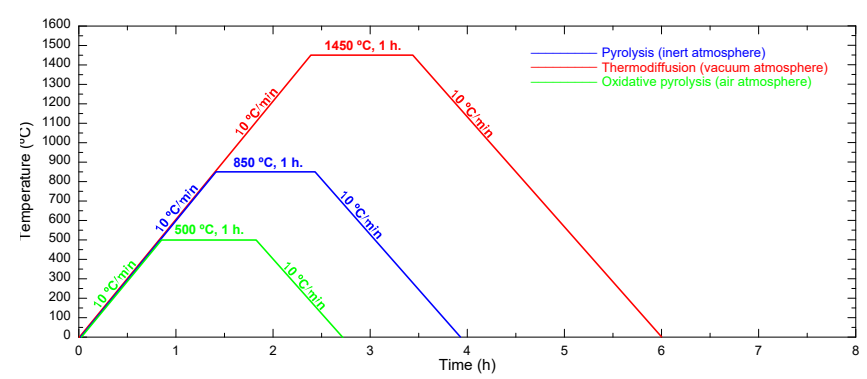

Fig. 1: Thermal profiles for inert pyrolysis (blue line), thermodiffusion (red line) and oxidative pyrolysis (green line) processes
Table 1: volumetric composition of the mortar mixtures studied

\begin{tabular}{cccc}
\hline sample & $\begin{array}{c}\text { fine sand } \\
\text { (vol.\%) }\end{array}$ & $\begin{array}{c}\text { portland } \\
\text { cement } \\
\text { (vol.\%) }\end{array}$ & $\begin{array}{c}\text { SiC powder } \\
\text { (vol.\%) }\end{array}$ \\
\hline A & 75 & 25 & 0 \\
B & 73 & 25 & 2 \\
C & 71 & 25 & 4 \\
D & 69 & 25 & 6 \\
E & 67 & 25 & 8 \\
\hline
\end{tabular}

All manufactured mortars were physically, microstructurally and mechanically characterized. The physical characterization consisted in the determination of real density by the technique of pycnometry, in this work a calibrated glass pycnometer and distilled water were used. The microstructural characterization was carried out on polished surfaces of the manufactured mortars. The preparation of the samples for microscopy began with a fine grinding of the surfaces, using SiC abrasive paper of \# 600, \# 800 and \# 1200 grain, then the surfaces were polished using diamond paste (6,3 and 1 micron) and lubricating liquid. The polished surfaces were cleaned with plenty of distilled water and allowed to air dry, no grain development technique was used. Microstructural observations were made in an AMSCOPE brand light microscope (50X - 500X), model ME320B-PZ (USA).

The mechanical tests consisted of uniaxial compression tests at a constant compression speed of $0.05 \mathrm{~mm} / \mathrm{min}$, in an air atmosphere and were executed in a universal testing machine, MICROTEST brand, model EM1/50/FR, (Spain). Samples for compression tests consisted of $10 \times 5 \times 5 \mathrm{~mm} 3$ parallelepipeds and were obtained from cylindrical samples of hardened mortars. Force and displacement data were obtained from the mechanical tests, which were then converted into stress vs. strain.

\section{Results and Discussion}

\subsection{Physical and Microstructural Characterization}

The real average density for all the materials studied was $2.1 \mathrm{~g} / \mathrm{cm} 3$. Fig. 2 shows optical microscopy micrographs of the five types of mortars studied, two well differentiated phases could be appreciated, on one hand, a continuous phase in dark gray contrast that corresponds to the agglomerating phase of Portland cement, and on the other hand, individual particles dispersed within the continuous phase are seen, corresponding to fine sand particles (light gray phase) and $\mathrm{SiC}$ particles (bright white phase). In the micrograph of the mortar with $8 \mathrm{Vol} \% \mathrm{SiC}$ powder, the identified phases are indicated (FS: fine sand, PC: Portland cement and SiC: silicon carbide powder) 

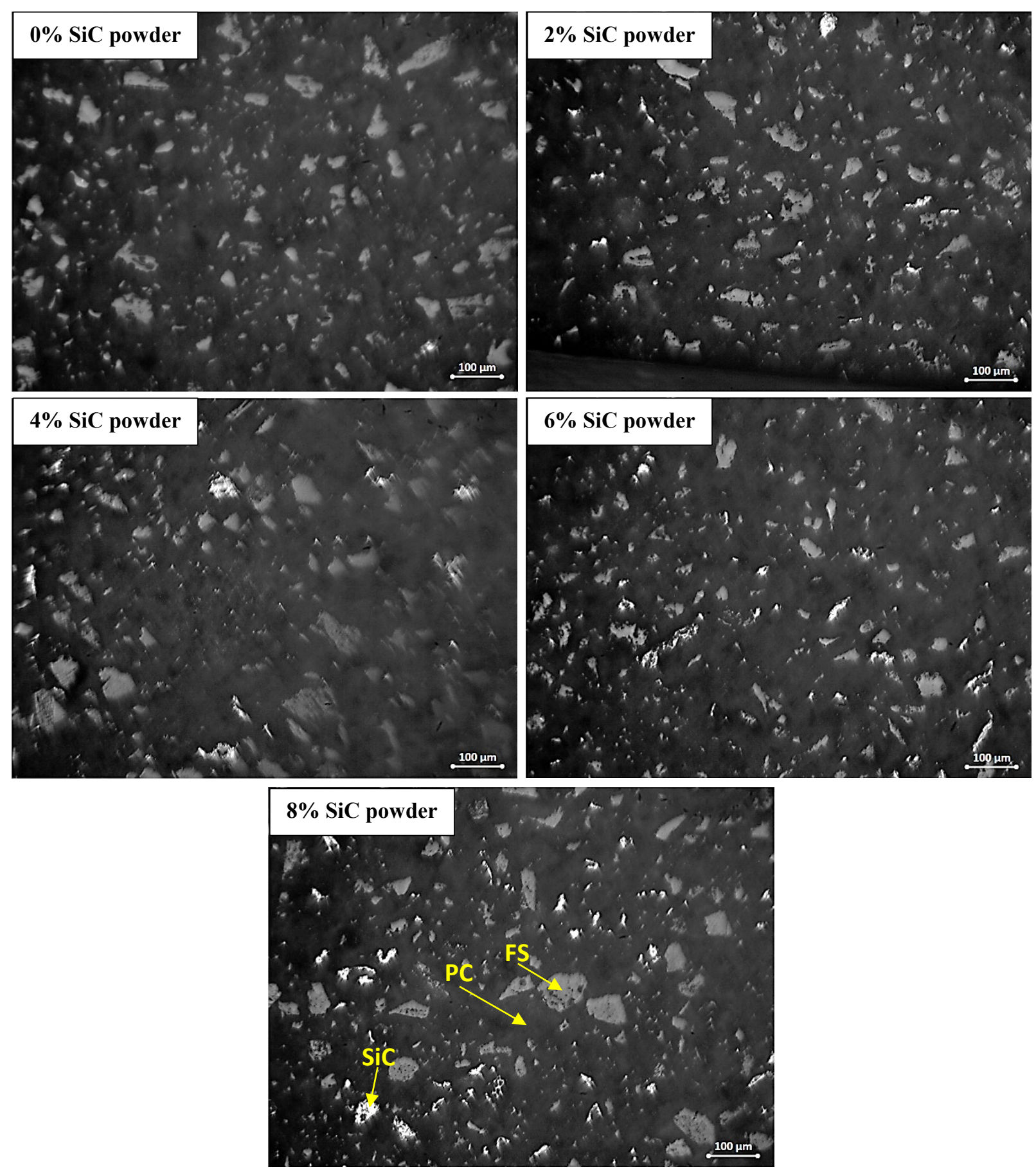

Fig. 2: Optical microscopy micrographs of cement Portland mortars with various percentages of SiC powder added.

\subsection{Mechanical Characterization}

Fig. 3 (a) presents stress vs. average strain for the five types of mortars studied, from these curves a slight increase in the deformation of mortars with added silicon carbide powder was observed, compared to mortars without the addition of $\mathrm{SiC}$ powder (curve in blue). It was also possible to observe a systematic increase in the average maximum resistance, as the percentage of $\mathrm{SiC}$ powder added to the Portland cement mortar mixtures increased, up to $4 \mathrm{Vol} . \%$ of $\mathrm{SiC}$ powder added. On 
the other hand, Fig. 3 (b) shows the relationship between the average maximum resistance and the percentage of SiC powder added, a maximum value of increase in mechanical resistance could be clearly appreciated (in comparison with mortar without $\mathrm{SiC}$ powder added) in mortars with 4 vol\%. of $\mathrm{SiC}$ powder added, however, increases greater than 4 Vol.\% $\mathrm{SiC}$ powder added led to a reduction in average maximum strength.
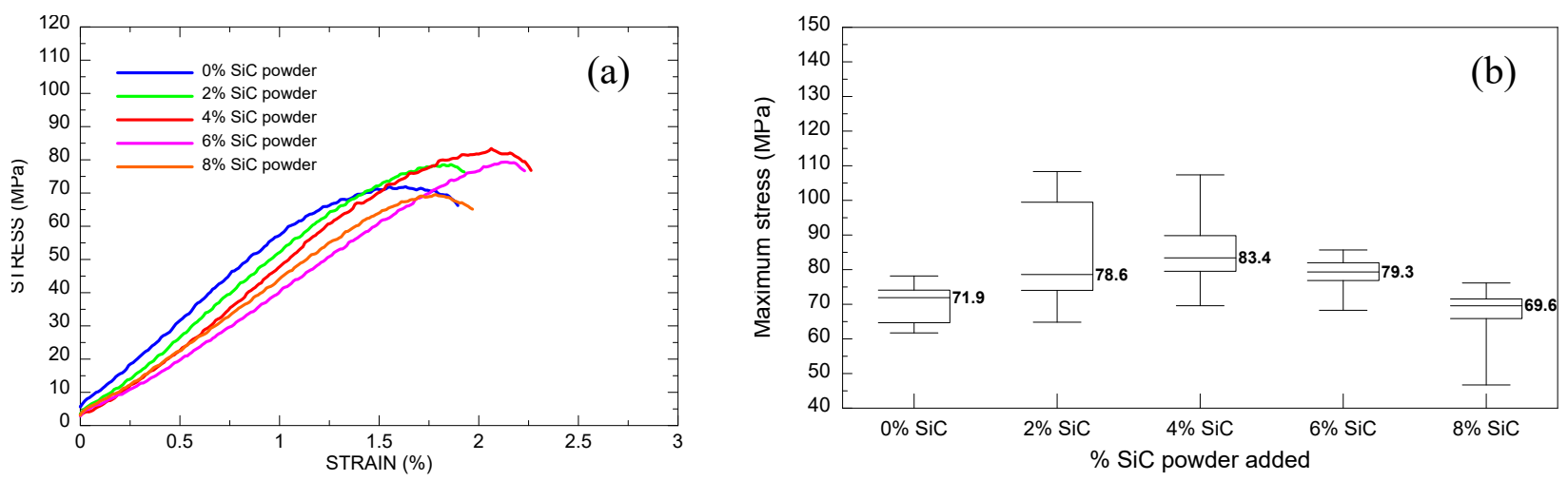

Fig. 3: (a) Stress vs. strain curves for the five types of mortars studied, (b) relationship between the maximum stress and the percentage of $\mathrm{SiC}$ powder added.

\section{Conclusions}

Portland cement mortars reinforced with silicon carbide powder, in various percentages, were successfully manufactured.

The average density found for all the mortars studied was $2.1 \mathrm{~g} / \mathrm{cm} 3$, which indicated that the addition of SiC particles to a mixture of conventional Portland cement mortar does not lead to increasing or reducing the density of the material after setting.

The microstructural evaluation revealed the presence of two well differentiated phases, on one hand, a continuous phase that corresponded to the agglomerating phase of Portland cement and, on the other hand, individual particles dispersed within the continuous phase, corresponding to the sand particles. fine and $\mathrm{SiC}$ powder.

The systematic increase of the average maximum resistance was evidenced, by increasing the percentage of $\mathrm{SiC}$ powder added to the Portland cement mortar mixtures, up to a value of 4 Vol.\% of SiC powder added, from which the maximum resistance decreases.

\section{Acknowledgements}

This work was financed by CONCYTEC - FONDECYT within the framework of call E041-01 with contract $\mathrm{N}^{\circ} 36$ 2018-FONDECYT-BM-IADT-AV and was executed in the laboratories of the Universidad Católica San Pablo.

\section{References}

[1] D. J. Lee, J. J. Jang, H. S. Park, Y. C. Kim, K. H. Lim, S. B. Park and S. H. Hong, "Fabrication of biomorphic SiC composites using wood preforms with different structures," Ceram. Int., vol. 38, no. 4, pp. 3089-3095, 2012, doi: 10.1016/j.ceramint.2011.12.008.

[2] M. Singh and J. A. Salem, "Mechanical properties and microstructure of biomorphic silicon carbide ceramics fabricated from wood precursors," J. Eur. Ceram. Soc., vol. 22, no. 14-15, pp. 2709-2717, 2002, doi: 10.1016/S09552219(02)00136-X.

[3] R.-M. JassoMata and Velásquez-Martínez, "Las masas forestales como sumideros de co2 ante un cambio climático global," Rev. Chapingo Ser. Ciencias For. y del Ambient., vol. 9, no. 1, pp. 57-67, 2003.

[4] V. C. Bringas-Rodríguez, F. A. Huamán-Mamani, J. J. Paredes-Paz, and J. F. Gamarra-Delgado, "Evaluation of thermomechanical behavior in controlled atmospheres of silicon carbide obtained from sawdust residues of the Peruvian timber industry," Mater. Today Proc., vol. 33, no. xxxx, pp. 1835-1839, 2020, doi: 10.1016/j.matpr.2020.05.175. 
[5] R. Sepúlveda, M. J. López Robledo, A. R. De Arellano López, J. Martínez Fernández, and C. Domínguez, “Aplicaciones del SiC biomórfico como reforzante estructural en hormigones refractarios," Boletín la Soc. Española Cerámica y Vidr., vol. 44, no. 5, pp. 357-362, 2005, doi: 10.3989/cyv.2005.v44.i5.370.

[6] K. M. Hyie, S. Budin, H. Elias, A. Kalam, and R. N. M. Masdek, "Fabrication of biomorphic silicon carbide from agriculture waste powders," Int. J. Mech. Eng. Robot. Res., vol. 6, no. 6, pp. 524-528, 2017, doi: 10.18178/ijmerr.6.6.524-528.

[7] O. G. Teixeira, R. H. Geraldo, F. G. da Silva, J. P. Gonçalves, and G. Camarini, "Mortar type influence on mechanical performance of repaired reinforced concrete beams," Constr. Build. Mater., vol. 217, pp. 372-383, 2019, doi: 10.1016/j.conbuildmat.2019.05.035.

[8] M. Deng, M. Zhang, F. Ma, F. Li, and H. Sun, "Flexural strengthening of over-reinforced concrete beams with highly ductile fiber-reinforced concrete layer," Eng. Struct., vol. 231, no. December 2020, p. 111725, 2021, doi: 10.1016/j.engstruct.2020.111725.

[9] C. G. Cho, B. C. Han, S. C. Lim, N. Morii, and J. W. Kim, "Strengthening of reinforced concrete columns by HighPerformance Fiber-Reinforced Cementitious Composite (HPFRC) sprayed mortar with strengthening bars," Compos. Struct., vol. 202, pp. 1078-1086, 2018, doi: 10.1016/j.compstruct.2018.05.045.

[10] G. D. Fischer, "Deformation behavior of reinforced ECC flexural members under reversed cyclic loading conditions," ProQuest Diss. Theses, vol. Ph.D., no. 100, pp. 25-35, 2002, [Online]. Available: http://sfx.scholarsportal.info/western?url_ver=Z39.88-

2004\&rft_val_fmt=info:ofi/fmt:kev:mtx:dissertation\&genre=dissertations+\%26+theses\&sid=ProQ:ProQuest+Disserta tions $+\% 26+$ Theses + Full + Text\&atitle $=\&$ title $=$ Deformation + behavior + of + reinforced + ECC + flexural + .

[11] G. Fischer and V. C. Li, "Deformation behavior of fiber-reinforced polymer reinforced engineered cementitious composite (ECC) flexural members under reversed cyclic loading conditions," ACI Struct. J., vol. 100, no. 1, pp. 2535, 2003, doi: 10.14359/12436. 